\title{
KONJUGE LİNOLEİK ASİT İLE ZENGİNLEŞTİRİLMİŞ YAĞIN YAĞSIZ SÜT TOZU VE MALTODEKSTRİN KARIŞIMI İLE MİKROENKAPSÜLASYONU VE MIIKROKAPSÜLLERİN KARAKTERIZZASYONU
}

\author{
Hakan Erinç, Hamza Alaşalvar* \\ ${ }^{*}$ Niğde Ömer Halisdemir Üniversitesi, Mühendislik Fakültesi, Gıda Mühendisliği Bölümü, Niğde, Türkiye \\ Geliş / Received: 28.09.2020; Kabul / Accepted: 21.10.2020; Online bask1 / Published online: 06.11.2020
}

Erinç, H., Alaşalvar, H. (2020). Konjuge linoleik asit ile zenginleştirilmiş yağın yağsız süt tozu ve maltodekstrin karışımı ile mikroenkapsülasyonu ve mikrokapsüllerin karakterizasyonu. GIDA (2020) 45(6)1143-1153 doi: 10.15237/gida.GD20111

Erinc, H., Alasalvar, H. (2020). Microencapsulation of an oil rich in conjugated linoleic acid with skimmed milk. powder and maltodextrin mixture and their characterization. GID A (2020) 45(6)1143-1153 doi: 10.15237/gida.GD20111

\section{ÖZ}

Konjuge linoleik asit (KLA), insan sağllğı üzerine birçok olumlu etkisi olan fonksiyonel bir bileşiktir. Fakat düşük oksidasyon stabilitesi ve suda çözünürlük özellikleri bu bileşenin gıdalarda kullanımını sınırlamaktadır. Bu çalışmada, KLA bakımından zenginleștirilmiş bir yağın püskürterek kurutma yoluyla enkapüslasyonunda kaplama maddesi olarak yağsız süt tozu ve maltodekstrinin farklı oranlarda kullanımının mikroenkapsülasyon verimi ve mikroenkapsülasyon etkinliği üzerine etkileri incelenmiştir. Mikroenkapsülasyon verimi ve mikroenkapsülasyon etkinliği sırasıyla \%21.35-42.92 ve \%16.32-73.91 değerleri aralı̆̆ında belirlenmiştir. Elde edilen verilere göre en uygun kaplama maddesi oranı $\% 70$ yağsız süt tozu ve $\% 30$ maltodekstrin içeren karışım olarak belirlenmiştir. Ayrıca, bu noktada elde edilen mikrokapsülerin moleküler, morfolojik ve termal özellikleri Fourier dönüşümlü kızılötesi spektrokopisi, taramalı elektron mikroskobu ve termogravimetrik analiz kullanılarak karakterize edilmiştir.

Anahtar kelimeler: Konjuge linoleik asit, yağsız süt tozu, maltodekstrin, püskürterek kurutma

\section{MICROENCAPSULATION OF AN OIL RICH IN CONJUGATED LINOLEIC ACID WITH SKIMMED MILK POWDER AND MALTODEXTRIN MIXTURE AND THEIR CHARACTERIZATION}

\begin{abstract}
Conjugated linoleic acid (CLA) is a functional compound that has many positive effects on human health. However, its low oxidation stability and water-solubility properties limit the use of this component in foods. In this study, the effects of different ratios of skimmed milk powder and maltodextrin on microencapsulation yield and microencapsulation efficiency were investigated in the microencapsulation of an oil-rich in CLA by spray drying. Microencapsulation yield and microencapsulation efficiency were determined in the range of $21.35-42.92 \%$ and $16.32-73.91 \%$, respectively. According to the data obtained, the optimum coating material ratio was determined as a mixture containing $70 \%$ skimmed milk powder and 30\% maltodextrin. In addition, the molecular, morphological, and thermal properties of the capsules obtained at this point were characterized using Fourier transform infrared spectroscopy (FTIR), scanning electron microscope (SEM), and thermogravimetric analysis (TGA).
\end{abstract}

Keywords: Conjugated linoleic acid, skimmed milk powder, maltodextrin, spray drying

* Yazışmalardan sorumlu yazar / Corresponding author;

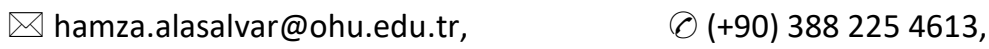

冝 $(+90) 3882250112$

Hakan Erinç; ORCID no: 0000-0001-8858-4570

Hamza Alaşalvar; ORCID no: 0000-0003-3000-7310 


\section{GİRIŞ}

İnsan sağlığ1 üzerine beslenmenin etkisinin bilimsel çalışmalar sonucu ortaya konulması ile sağlıklı gidalar için tüketici talebi gün geçtikçe artmaktadır. Bu amaçla, birçok biyoaktif bileşik çeşitli gida ürünlerinin zenginleştirilmesi için yaygın bir şekilde kullanılmaktadır. Vitaminler, mineraller, antimikrobiyal maddeler, fenolik bileşikler, antioksidanlar ve biyoaktif lipidler bu fonksiyonel gida bileşenleri arasındadır. $\mathrm{Bu}$ bileşenleri gidalara veya içeceklere direkt olarak uygulamada düşük çözünürlük, kimyasal bozulma, duyusal özelliklerin kaybı, oksidasyon gibi çeşitli olumsuz durumlar ortaya çıkabilmektedir (Labuschagne, 2018; Torres-Giner vd., 2010) .

Konjuge linoleik asit (KLA), antikanser, antidiyabetik ve antihipertansif özellikler sergileyen çoklu doymamış bir yağ asididir (Y. Kim, Kim, Whang, \& Park, 2016). Et ve süt ürünlerinde belirli miktarlarda KLA bulunmaktadır ancak insan vücudu tarafindan sentezlenemez (Choque vd., 2014). Bu sebeple KLA tüketiminin artırılması için gıdalara dışardan ilave edilmesi gerekmektedir. Ancak KLA oksidasyona maruz kaldığında biyoaktif özelliklerini kolaylikla kaybedebilmektedir (Fernandez-Avila vd., 2016). Ayrıca, KLA'nın sudaki düşük çözünürlüğü yüksek oranda su içeren gıdalara KLA ilavesini zorlaştırmaktadır. KLA' nın sudaki çözünürlügünü ve oksidasyon stabilitesi artırmak için kullanılan yaygın işlemlerden birisi mikroenkapsülasyondur (Costa vd., 2015).

Mikroenkapsülasyon işleminde yüksek verimliliği, kolay ulaş1labilirliği ve düşük işlem maliyetinden dolayı en yaygin kullanılan yöntem püskürterek kurutma metodudur (Kalušević vd., 2017). Yağların mikroenkapsülasyonunda ilk aşamada kaplama maddesi kullanılarak su içinde yağ emülsiyonu elde edilir ve daha sonra kurutma işlemi gerçekleştirilir. $\mathrm{Bu}$ sebeple emülsiyon oluşturma özelliği gösteren kaplama maddelerinin kullanılmas1 gerekmektedir. Karbonhidratlar, lipidler ve proteinler gibi farklı kaplama maddeleri mikroenkapsülasyon işlemlerinde yaygin olarak kullanılmaktadır (F. Gibbs, 1999). Karbonhidrat esaslı kaplama maddeleri zayıf emülsiyon özelliği sergiledikleri için yağların mikroenkapsülasyonunda tek başina kaplama maddesi olarak kullanılmazlar (Kagami et al., 2003). Ancak, diğer kaplama maddeleri ile kombine edildiklerinde mikroenkapsülasyon etkinliğini ve verimini geliştirmektedir (Aghbashlo vd., 2012). Yağsız süt tozu, protein içeriğinden dolayı emülsifiye edici özellĭği vardır, ayrıca ulaşılabilirliğinin kolay olması ve fiyatının da diğer kaplama materyallerine göre ucuz olmasından dolayı mikroenkapsülasyon işlemlerinde kullanılmaktadır (Goula ve Adamopoulos, 2012). Nar çekirdek yağı (Goula ve Adamopoulos, 2012) ve ceviz yağ1 (Shamaei vd., 2017) yağsız süt tozu kullanılarak mikroenkapsüle edilmiştir.

Literatürde KLA' nın mikroenkapsülasyonu üzerine olan çalışmalar incelendiğinde, bu çalışmalar genellikle serbest yağ asidi olarak KLA' nın mikroenkapsülasyonu üzerine odaklanmıstır (Costa vd., 2015; Jimenez vd., 2004, 2006; Kim vd., 2000; Lee vd., 2009). Ancak, yalnızca bir çalışmada KLA bakımında zenginleştirilmiş bir yağın (Tonalin TG 80) mikroenkapsülasyonu rapor edilmiştir (Holgado vd., 2018).

Sunulan bu çalısmada, konjuge linoleik asit bakımından zenginleştirilmiş bir yağın mikroenkapsülasyonunda yağsız süt tozu ve maltodekstrinin mikroenkapsülasyon etkinliği ve verimi üzerine etkilerinin Simplex Lattice deneme deseni kullanılarak incelenmesi amaçlanmıştır. Optimum noktada elde edilen mikrokapsüller taramal1 elektron mikroskobu, Fourier Dönüşümlü Kızılötesi Spektroskopisi ve termogravimetrik analiz kullanılarak karakterize edilmiştir.

\section{MATERYAL VE YÖNTEM}

\section{Materyal}

Maltodekstrin (Dekstroz eșdeğeri:13-17) ve diğer kimyasallar Sigma şirketinden temin edilmiştir. Çalışmada kullanılan \%1 yağ içeriğine sahip yağsız süt tozu (Pınar, İzmir, Türkiye) Niğde'de bulunan yerel bir marketten temin edilmiştir. Analizde kullanılan kimyasallar analitik saflıktadır. 


\section{Metot}

KLA ve KLA bakımından zenginleştirilmiş yağ üretimi

KLA üretimi, aspir yağı başlangıç materyali olarak kullanılarak Alaşalvar vd., (2019) tarafindan tanımlanan metoda göre gerçekleştirilmiştir. Özetle, aspir yağ1 $(250 \mathrm{~g})$, potasyum hidroksit $(57.5 \mathrm{~g})$, etanol $(200 \mathrm{~mL})$ ve saf su $(60 \mathrm{~mL})$ kullanılarak kaynama noktasına kadar isıtılarak 1 saat içinde sabunlaştırılmıştır. Bu işlemden sonra $250 \mathrm{~mL}$ soğutulmuş saf su ve $300 \mathrm{~mL} 4 \mathrm{M}$ sülfirik asit bu karışım üzerine eklenmiş ve $\mathrm{pH} 2$ olacak şekilde ayarlanmıştır. Dietil eter kullanılarak karşım içerisinden serbest yağ asitleri ayrilmıştır. Linoleik asitin saflaştırılması için aseton kullanılmış ve örnekler $-70^{\circ} \mathrm{C}$ 'de kristalize edilmiştir. Kristalizasyondan sonra \%88.2 oranında linoleik asit içeren bir fraksiyon elde edilmiştir. Linoleik asitten KLA eldesi için potasyum hidroksit: LA bakımından zengin fraksiyon: Etilen glikol oranları 1:4.8:7.7 olacak şekilde karıştırılmış ve $700 \mathrm{~W}$ mikrodalga gücünde 6 saat reaksiyona bırakılmışıtır.

\section{KLA bakımından zengin yağ üretimi}

KLA ile zenginleştirilmiş yağın üretiminde Güney $\mathrm{vd}$, (2020) tarafindan belirtilen metot kullanılmıştır. $\mathrm{Bu}$ işlem için palm stearin ve metillendirilmiş-KLA oranı $1 / 3$ olacak şekilde ayarlanmıştır. Manyetik karıştırıcı kullanılarak vakum ortamında yağın sicakllğ $90^{\circ} \mathrm{C}^{\prime} \mathrm{ye}$ getirilerek $15 \mathrm{dk}$ süreyle karıştırılması ile nemi uzaklaştırılmışır. Katalizör olarak \%30'luk sodyum metilat çözeltisinden yağın $\% 0.5$ ' oranında karışıma eklenerek 30 dakika süre ile 90 ${ }^{\circ} C^{\prime}$ de vakum altında isıtılmıştır. Reaksiyon tamamlandıktan sonra katalizörün inaktif hale getirilmesi için toplam yağ ağırlığının \%2'si oranında \%20'lik sitrik asit çözeltisi karışıma eklenmiş ve aynı sıcaklıkta 15 dakika karıştırma işlemine devam edilmiştir. Yağlar ağartma toprağ kullanılarak kâğıt filtreden süzülerek katalizör ve yabancı maddeler uzaklaştırılmıştır.

\section{Mikrokapsüllerin üretimi}

Mikrokapsüllerin üretiminde ilk aşamada yağ/kaplama maddesi oranı $1 / 2$ olacak şekilde ağırlıkça \%30 kuru madde içeren emülsiyonlar hazırlanmıştır. Kaplama maddesi kompozisyonunun mikroenkapsülasyon üzerine etkilerinin incelenmesi amaciyla yağ ve kuru madde miktarları sabit tutularak kaplama maddesi içeriği Simplex Lattice deneme desenine (Çizelge 1) göre 8 noktada değiştirilmiştir. Püskürterek kurutma işleminden önce elde edilen karışımlar Ultra-Turrax T18 (IKA®-Werke GmbH \& Co. KG, Staufen, Almanya) kullanilarak ile 10000 rpm'de 10 dakika homojenize edilmiştir. Püskürterek kurutma işlemi Büchi B-290 (Büchi, Flawil, İsviçre) cihazı kullanılarak hava giriş sıcaklı̆g $180^{\circ} \mathrm{C}$, çıkış sıcaklı̆g $91 \pm 3^{\circ} \mathrm{C}$, hava akış hız1 $600 \mathrm{~L} /$ saat, besleme hız1 $8 \mathrm{~mL} /$ dakika olacak şekilde ayarlanmıştır. Elde edilen mikrokapsüller $4^{\circ} \mathrm{C}$ 'de cam kaplar içerisinde muhafaza edilmiştir.

\section{Mikroenkapsülasyon verimi}

Mikroennkapsülasyon veriminin hesaplanmasında, emülsiyon hazırlamak için kullanılan kuru madde miktarı ve püskürterek kurutma sonucunda elde edilen toz ürün miktarı arasındaki ilişki kullanılarak aşağıdaki denklemde belirtilen şekilde hesaplanmıştır (Başyiğit vd., 2020).

\footnotetext{
Enkapsülasyon verimi(\%)

$=\frac{\text { Püskürterek kurutma sonrası elde edilen toz ürün miktarı }}{\text { Emülsiyonda kullanılarak kuru madde miktarı }} * 100$
}

\section{Yüzey yağ miktarı}

Yüzey yağ mikroekapsülasyon işleminden sonra mikroenkapsüle olmamış olan yağı ifade etmektedir. Mikrokapsüllerin yüzeyindeki yă̆ miktarının belirlenmesinde, $1 \mathrm{~g}$ mikrokapsül üzerine $5 \mathrm{~mL}$ petrol eteri ilave edilerek 5 dakika karıştırılmışır. Karıştırma işleminden sonra Whatmann no.1 filtre kâğıdı kullanılarak sabit tartıma getirilmiş kaplara eksrakte edilen yăg süzülmüştür. Mikrokapsüller üzerine 3 kez daha 5 $\mathrm{mL}$ petrol eteri ilavesi gerçekleştirilerek kalan yağın ekstrakte edilmesi sağlanmıştır. Petrol eteri yağ karışımından petrol eterinin uzaklaştırılması $40^{\circ} \mathrm{C}$ 'de döner buharlaştırıcı yardımıyla sağlanmıştır (Roccia vd., 2014). Sonrasında elde edilen yağ $103^{\circ} \mathrm{C}$ 'de 1 saat kurutulmuştur.

\section{Toplam yağ miktarı}

Mikrokapsüllerdeki toplam yağın belirlenmesi, $2 \mathrm{~g}$ mikrokapsül üzerine $90 \mathrm{~mL}$ metanol/kloroform $(1 / 2)$ karışımı ve $\% 2$ oranında $\mathrm{NaCl}$ içeren $10 \mathrm{~mL}$ 
su ilave edilmiştir. Elde edilen karışım ayırma hunisi içeresinde hafifçe karıştırılmış ve faz ayrımı için 10 dakika beklenilmiştir. Faz ayrımından sonra altta kalan faz sabit tartıma getirilmiş kap içerisine alınmıştır. Çözücünün uzaklaştırılmasında $40^{\circ} \mathrm{C}$ 'de döner buharlaştırıcı kullanılmıştır. Sonrasında elde edilen yağ $103^{\circ} \mathrm{C}$ 'de 1 saat kurutulmuştur (Velasco vd., 2006).

\section{Mikroenkapsülasyon etkinliği}

Mikrokapsüllerdeki toplam yağ miktarı ve mikrokapsüllerin yüzeyindeki yağ miktarı arasındaki ilişki kullanılarak aşağıdaki şekilde hesaplanmıştır (Tonon vd., 2011).

$$
\text { Enkapsülasyon Etkinliği }(\%)=\frac{\text { Toplam yağ }- \text { Yüzey yağ }}{\text { Toplam yağ }} * 100
$$

\section{Su aktivitesi}

Mikrokapsüllerin su aktivitesi değerleri su aktivitesi tayin cihaz1 (AquaLab Series 3, ABD) kullanılarak $25^{\circ} \mathrm{C}$ 'de ölçülmüştür.

\section{Mikrokapsüllerin akış özellikleri}

Mikrokapsüllerin yığın yoğunluğu $\left(\mathrm{kg} / \mathrm{m}^{3}\right), 10$ $\mathrm{mL}$ hacme sahip mezür içerisine $2 \mathrm{~g}$ mikrokapsül hava boşluğu kalmayacak şekilde ancak herhangi bir basınç uygulamaksızın doldurulmuş ve kütle/hacim oranından hesaplanmıştır. Sıkıştırılmış yoğunluk $\left(\mathrm{kg} / \mathrm{m}^{3}\right)$ ise, $2 \mathrm{~g}$ toz örneğin $10 \mathrm{~mL}$ hacme sahip silindirik kabın içerisine doldurulup saniyede 1 vuruş olacak şekilde 180 kez vurularak sıkıştırılması ile kütle/hacim oranından belirlenmiştir (Jinapong, Suphantharika, \& Jamnong, 2008). Ylğın ve sıkıştırılmış yoğunluk değerlerinden yararlanılarak Carr indeks (CI) değerleri ve Hausner oranları (HO) hesaplanmıştır (Velasco vd., 2006).

\section{Termogravimetrik analiz}

Üretilen mikrokapsüllerin termogravimetrik analizleri Linseis marka termogravimetri cihazı kullanilarak azot atmosferinde $0-500^{\circ} \mathrm{C}$ sicaklik aralığında ve $10^{\circ} \mathrm{C} /$ dakika 1 sitma hizında gerçekleştirilmiştir (Başyiğit vd., 2020).

\section{Fourier dönüşümlü kızılötesi spektroskopisi} Elde edilen ürünlerin FTIR ölçümlerinde $\mathrm{KBr}$ ile hazırlanan pelletler kullanılmıştır. Dalga boyları
$4000-400 \mathrm{~cm}^{-1}$ arasında spektrum taranmıştır (Başyiğit vd., 2020).

\section{Taramalı elektron mikroskobu}

Mikrokapsüllerin morfolojik yapılarının belirlenmesi taramalı elektron mikrokobu (Zeiss, Almanya) kullanilarak $750 \mathrm{x}$ ve $2.5 \mathrm{Kx}$ büyütme oranlarında vakum altında gerçekleştirilmiştir.

\section{İstatistiksel analizler}

Mikrokapsüllerin üretimi iki tekrarlı olarak gerçekleştirilmiş ancak ölçümler üç tekrarlı olarak yürütülmüştür. Design expert 7 (Stat-Ease Inc., Minneapolis, ABD) programı yardımiyla varyans analizi (ANOVA) kullanilarak kaplama maddesi kombinasyonlarının mikroenkaspsülasyon verimi ve etkinliği üzerine etkileri belirlenmiştir. Çoklu cevapların eş zamanlı optimizasyonu için arzu edilebilirlik fonksiyonu kullanılmışır. Optimum noktada elde edilen tozların doğrulama analizleri Student- t test kullanılarak \%95 güven aralığında SPSS 21 (Şikago, ABD) programında gerçekleştirilmiştir.

\section{SONUÇ VE TARTIŞMA}

KLA içeriği bakımından zenginleştirilmiş yă̆ mikrokapsülerinin mikroenkapsülasyon verimi, mikroenkapsülasyon etkinliği, su aktivitesi, yığın yoğunluk, sıkıştırılmış yoğunluk, Carr indeks ve Hausner oranı değerleri Çizelge 1'de verilmiştir. Mikroenkapsülasyon verimi, püskürterek kurutma işleminde sonra geri kazanılan toz ürün miktarını ifade etmektedir. Kaplama maddesi kombinasyonuna bağlı olarak örneklerin mikroenkapsülasyon verimi $\% 21.35$ ile 42.92 değerleri aralığında değişmiştir. Kaplama maddesi olarak yağsız süt tozu ile maltodekstrinin birlikte kullanımı geri kazanılan toz miktarını artırmıstır.

Mikroenkapsülasyon etkinliği \%16.32 ve 73.91 değerleri arasında değişmiştir. Kaplama maddesi olarak sadece maltodekstrin kullanılarak üretilen mikrokapsüller en düşük etkinlik değerine sahiptir. $\mathrm{Bu}$ bulgu maltodekstrinin düşük emülsiyon özelliği ile açıklanabilir. Formülasyonlarda sadece yağsız süt tozu veya yağsız süt tozu-maltodekstrin karışımı kullanıldığında daha yüksek etkinlik değerleri elde edilmiştir. Bu durum yağsız süt tozunun protein 
içeriği ile dolayısıyla emülsifiye edici özelliği ile açıklanabilir. Farklı kaplama maddeleri (peynir alt suyu proteinleri, sodyum kazeinat ve yağsız süt tozu) ve farklı sicakliklar $\left(140,160\right.$ ve $\left.180^{\circ} \mathrm{C}\right)$ ile balık yağının mikroenkapsülasyonunun gerçekleştirildiği bir çalışmada, kaplama maddesi olarak yağsız süt tozu ve $180^{\circ} \mathrm{C}$ giriş sıcaklığ kullanıldığında etkinlik değeri \%81.94 olarak belirlenmiştir (Aghbashlo vd., 2013). Bir diğer çalışmada, yağsız süt tozu, yağsız süt tozu+Tween 80 ve yağsız süt tozu+maltodekstrin ceviz yağının mikroenkapsülasyonunda kaplama maddesi olarak kullanılmış ve $\% 90$ mikroenkapsülasyon etkinliği yağsız süt tozu+Tween 80 kullanıldığında elde edilmiştir. Yağsız süt tozu maltodekstrin karışımı kullanıldığında ise etkinlik değeri \%56.19 olarak rapor edilmiştir (Shamaei vd., 2017).

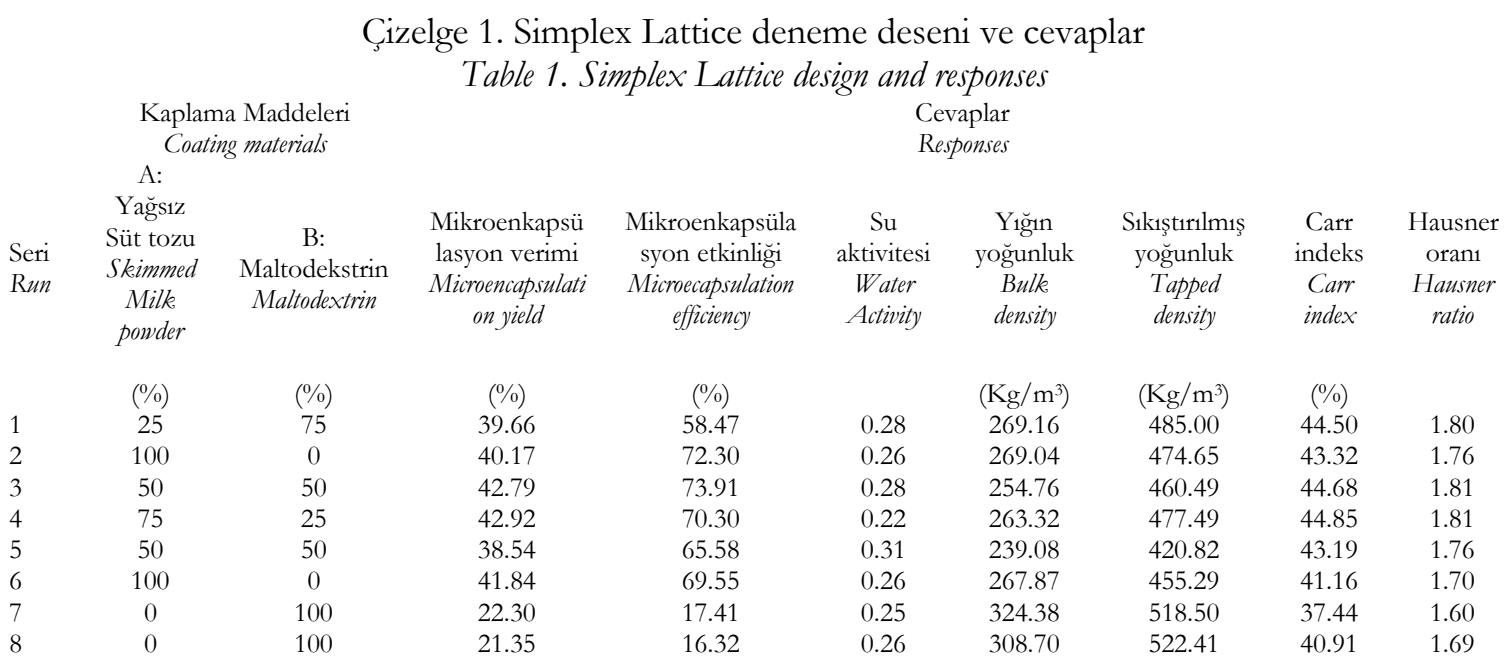

Mikrokapsüllerin su aktivitesi değerleri 0.25-0.31 değerleri arasında belirlenmiştir. Elde edilen su aktivitesi değerleri uzun süreli depolamalarda mikrokapsüllerin mikrobiyal güvenliğini sağlamak açısından uygundur. Süt tozu kullanılarak antosiyaninlerce zengin bir ekstraktın mikroenkapsülasyonunda su aktivitesi değeri 0.32 olarak rapor edilmiştir (Kalušević vd., 2017).

Yığın yoğunluk toz örneklerin partikül boyutundan etkilenmektedir. Küçük boyutlu partiküllerin yüksek miktarda bulunmas1 yoğunluğu artırmaktadır (Nath ve Satpathy, 1998). Yığın ve sıkıştırılmış yoğunluk değerleri, sadece maltodekstrin kullanilarak üretilen örnekler ile kıyaslandığında yağsız süt tozu içeren örneklerde azalmıştır. Sıkıştırılmış yoğunluk ve yığın yoğunluk arasındaki yüksek orandaki fark ürünlerin akabilirliğinin kötü olduğunu ve kekleşmenin yüksek olduğunu göstermektedir. Yağ/yağsız süt tozu oranı, emülsiyonun kuru madde oran1, püskürtmeli kurutucu giriş sıcakllğı ve kuru hava akış hızı gibi faktörlere bağlı olarak nar çekirdek yağının yığın yoğunluğu 200 ile 600 $\mathrm{kg} / \mathrm{m}^{3}$ aralığında değiştiği rapor edilmiştir (Goula ve Adamopoulos, 2012). Hausner oraninin 37.44 ile 44.50 değerleri arasında ve Carr indeks değerlerinin 1.4'ten büyük olması elde edilen mikrokapsüllerin akış özelliklerinin kötü olduğunu göstermektedir.

\section{Uygun kaplama maddesi karışımının belirlenmesi}

Simplex Lattice deneme desenine göre yürütülen analizlerden elde edilen sonuçlara göre mikroenkapsülasyon verimi ve etkinliği üzerine yağsız süt tozu ve maltodekstrin kullanımının etkileri Design Expert programı kullanilarak incelenmiştir. Modellerin önemi ve uygunluğu ANOVA kullanılarak belirlenmiştir. ANOVA sonuçları ve modellerin katsayıları Çizelge 2'de verilmiştir. Mikroenkapsülasyon verimi ve etkinliği için sırayla 0.9317 ve $0.9632 \mathrm{R}^{2}$ değerleri ile kuatratik modeller uygun bulunmuştur. Mikroenkapsülasyon verimi için yüksek tahmin edilen- $R^{2}=0.8613$ ve ayarlanmış- $R^{2}=0.9044$ 
değerleri arasındaki farkın 0.2'ten düşüktür. Ayrıca modelin doğruluğunu gösteren uyum eksiği değeri istatistiksel $(P>0.05)$ olarak önemsizdir. Enkaspsülasyon verimi üzerine yağsız süt tozu ve maltodekstrinin bireysel ve karışım olarak kullanımı istatistiksel $(P<0.001)$ olarak önemli bulunmuştur. Mikroenkapsülasyon etkinliği için tahmin edilen- $\mathrm{R}^{2}$ ve ayarlanmış- $\mathrm{R}^{2}$ değerleri arasındaki fark mikroenkapsülasyon verimi ile benzer şekilde 0.2 'den küçüktür. Uyum eksikliği değeri istatistiksel $(P>0.05)$ olarak önemsizdir. ANOVA sonuçlarına göre yağsız süt tozu ve maltodektrin karışımının kullanımı mikroenkapsülayon etkinliği üzerine istatistiksel olarak ( $P=0.0015)$ önemli düzeyde etkilidir.

Çizelge 2. Mikroenkapsülasyon verimi ve etkinliği için ANOVA sonuçları

\begin{tabular}{|c|c|c|c|}
\hline Bileşenler & Katsayılar & Mikroenkapsülasyon verimi & Mikroenkapsülasyon etkinliğ \\
\hline Component & Coefficient & Microencapsulation yield & Microecapsulation efficiency \\
\hline $\begin{array}{l}\text { A-Yağsiz süt tozu } \\
\text { Skimmed milk powder }\end{array}$ & $\beta_{1}$ & +39.99 & +67.07 \\
\hline $\begin{array}{l}\text { B-Maltodekstrin } \\
\text { Maltodextrin }\end{array}$ & $\beta_{2}$ & +22.44 & +18.18 \\
\hline $\mathrm{AB}$ & $\beta_{12}$ & +40.31 & +108.55 \\
\hline $\mathrm{R}^{2}$ & & 0.9317 & 0.9632 \\
\hline $\begin{array}{l}\text { Ayarlanmiş- } \mathrm{R}^{2} \\
\text { Adjusted-R }\end{array}$ & & 0.9044 & 0.9485 \\
\hline $\begin{array}{l}\text { Tahmini } \mathrm{R}^{2} \\
\text { Predicted-R } \mathrm{R}^{2}\end{array}$ & & 0.8613 & 0.9169 \\
\hline $\begin{array}{l}\text { p-değeri } \\
\text { p-value }\end{array}$ & & 0.0012 & 0.0003 \\
\hline $\begin{array}{l}\text { F değeri } \\
F \text { value }\end{array}$ & & 34.12 & 65.50 \\
\hline $\begin{array}{l}\text { Uyum eksikliği } \\
\text { Lack of fit }\end{array}$ & & 0.1187 & 0.2404 \\
\hline
\end{tabular}

En uygun kaplama maddesi karışımının seçiminde mikroenkapsülasyon verimi ve etkinliği değerlerinin maksimum olduğu noktanın belirlenmesi amaçlanmıştır. En uygun kaplama maddesi oranı $\% 70$ yağsız süt tozu ve $\% 30$ maltodekstrin içeren karşım olarak bulunmuştur. $\mathrm{Bu}$ noktada tahmin edilen mikroenkapsülasyon verimi ve etkinliği değerleri sırasıyla $\% 43.1927$ ve 75.2005 olarak belirlenmiştir (Şekil 1). Bu kaplama maddesi karışımı kullanılarak yürütülen püskürterek kurutma işleminde mikroenkapsülasyon verimi ve etkinliği değerleri $\% 42.98 \pm 1.05$ ve $\% 75.85 \pm 0.92$ olarak belirlenmiş ve elde edilen sonuçlar arasında istatistiksel olarak bir fark yoktur. Bu bulgu yağsız süt tozu ve maltodekstrinin farklı oranlarda kullanımının kuatratik modeller ile açıklanabileceğini göstermektedir.

\section{Moleküler özellikler}

Kaplama maddeleri (yağsız süt tozu ve maltodekstrin), KLA bakımından zengin yağ ve mikrokapsüllerin FTIR spektrumları Şekil 2'de verilmiştir. FTIR analizi mikrokapsülleri oluşturan bileşenler arasındaki etkileşimi belirlemek için kullanılmaktadır. KLA bakımından zengin yağ için $2923.09 \mathrm{~cm}^{-1}$ de elde edilen pik hidrokarbon zincirindeki asimetrik yağ asitlerini ifade etmektedir (Kadamne vd., 2009). Benzer şekilde mikrokapsüllerde gözlenen ancak yağsız süt tozu ve maltodekstrinde gözlenmeyen $2923.14 \mathrm{~cm}^{-1}$ 'deki pik mikrokapsüllerin yüzeyinde yağın varlığının bir göstergesidir. Deformasyonlar ve bükülme bölgelerinde bulunan ve tüm örneklerde ölçülen $1461.20 \mathrm{~cm}^{-1}$ yer alan pikin hem $\mathrm{CH}_{2}$ ve $\mathrm{CH}_{3}$ alifatik gruplarının bükülme titreşimlerini belirttiği hem de yağlarda toplam doymamışlık derecesini göstermektedir. Çift bağ 
gerilim bölgesinde yer alan 1800-1600 $\mathrm{cm}^{-1}$ bandında görülen $1743 \mathrm{~cm}^{-1}$ 'deki pik trigliseridlerin karbonil ester fonksiyonel gruplarını belirtmektedir (Roach vd., 2002). Trans, trans KLA izomerleri, $988 \mathrm{~cm}^{-1}$ 'de bir pik üretirken ve cis, trans KLA izomerleri, sirasiyla 981 ve $947 \mathrm{~cm}^{-1}$ 'de iki pik üretmektedir (Christy vd., 2003). Buna göre $983,71 \mathrm{~cm}^{-1}$ de yer alan bandin trans, trans KLA izomerinden
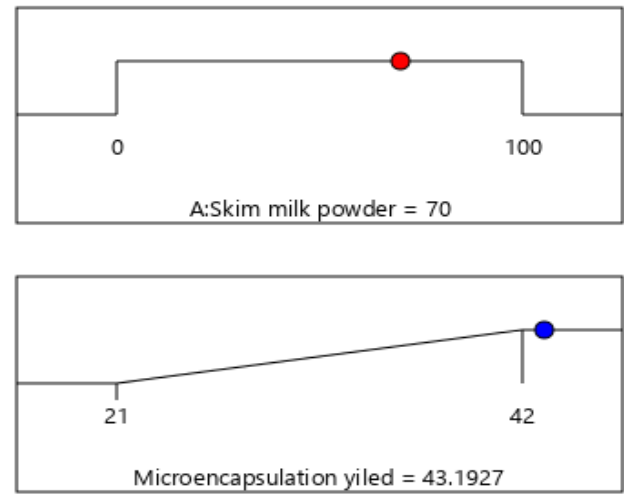

kaynaklandığ1 düşünülmektedir. Bu karakteristik piklerin mikrokapsüllerde görülmemiş olması kaplama maddesi ile KLA ile zenginleştirilmiş yağ arasında herhangi bir reaksiyonun olmadığını göstermektedir. Bu bulguya göre KLA bakımında zengin yağın yağsız süt tozu ve maltodekstrin karışımında mikrokapsüllenmesi kimyasal reaksiyondan ziyade fiziksel bir etki ile gerçekleşmektedir.
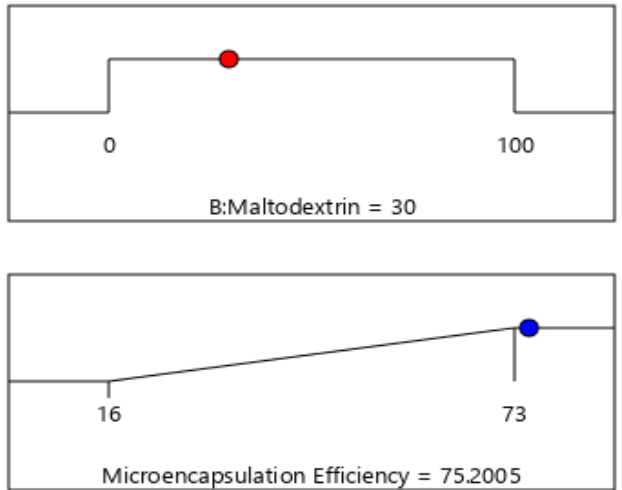

SSekil 1. Optimum kaplama maddesi oranları ve tahmin edilen değerler Figure 1. Optimum coating material ratios and predicted values

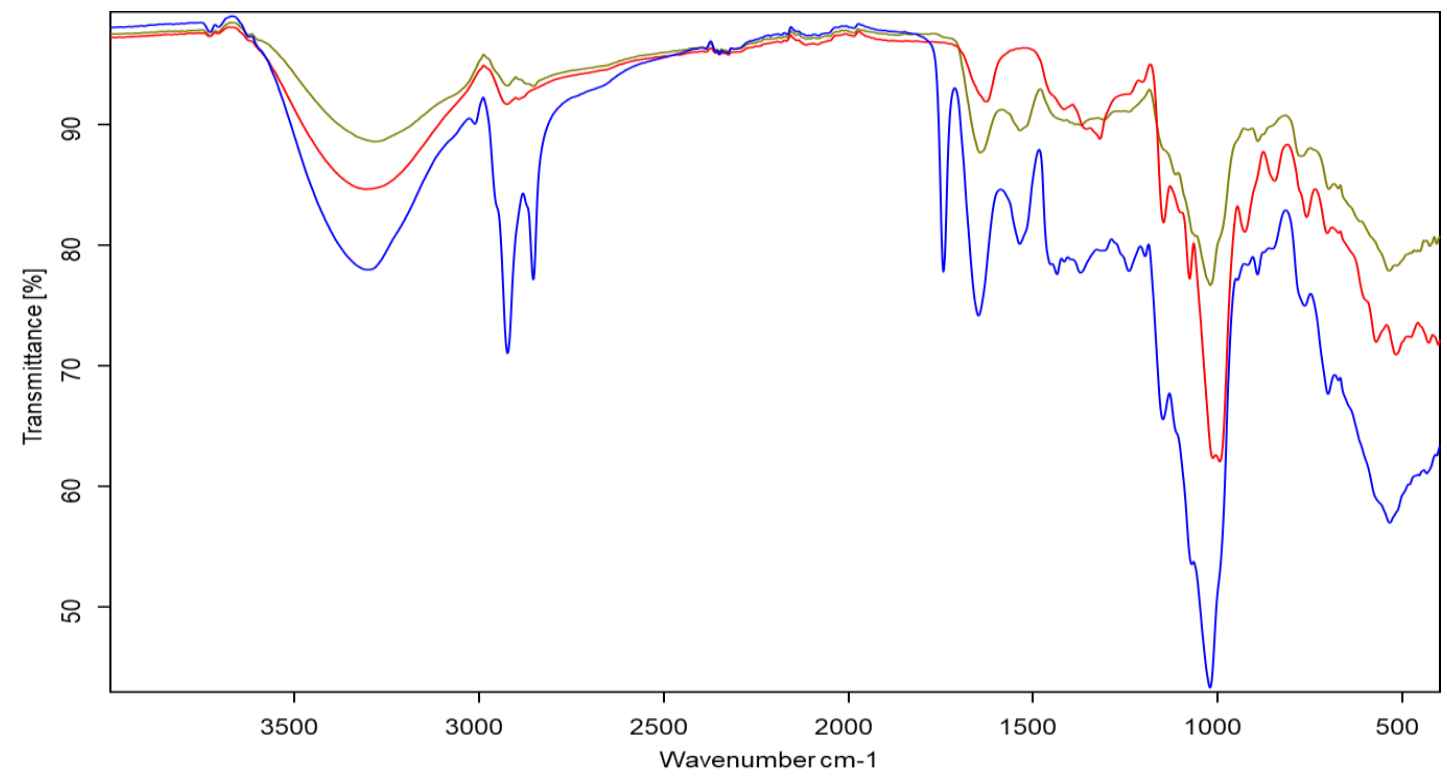

Şekil 2. Yağsız süt tozu (Yeşil), Maltodekstrin (Kırmızı) ve mikroenkapsüle tozlara (Mavi) ait Fourier dönüşümlü kızıl ötesi spektrumları

Figure 2.Fourier transformed infrared spectra of milk. powder (Green), maltodextrin (Red) and encapsulated powders (Blue) 


\section{Termal özellikler}

Yağsız süt tozu, maltodekstrin ve mikrokapsüllerin termal özellikleri termogravimetrik analiz yolluyla belirlenmiştir. Örneklere ait ağırlık kaybı eğrileri Şekil 3’te verilmiştir. Elde edilen eğriler arasındaki farkllıklar örneklerin farklı bozulma mekanizmaları gösterdiğini ortaya koymaktadır. Termogravimetrik eğriler incelendiğinde 100$200^{\circ} \mathrm{C}$ aralı̆̆ında maltodekstrinin diğer örneklere kıyasla daha yüksek termal dayanıklılık gösterdiği belirlenmiştir. Yağsız süt tozu ve mikrokapsüller için ilk dikkate değer termal parçalanma 175$182^{\circ} \mathrm{C}$ aralığında meydana gelirken maltodekstrin için $252^{\circ} \mathrm{C}$ 'de kütlede önemli değişimler gözlenmiştir. Yağsız süt tozu ve mikrokapsüller $300^{\circ} \mathrm{C}$ sicaklığa kadar benzer termogravimetrik özellikler göstermiştir. Ancak $300^{\circ} \mathrm{C}$ sicaklıktan sonra hem maltodektrinin hem de yağsız süt tozunun özelliklerine bağlı olarak farklı bir eğri elde edilmiştir. Analiz sonucunda $500^{\circ} \mathrm{C}$ sicaklık uygulandığında, mikroenkapsüle toz ve maltodekstrinin kütlelerinde sirasiyla $\% 68$, 84 ve 99 kayıp meydana gelmiştir. $\mathrm{Bu}$ sonuçlar göstermektedir ki hem yağsız süt tozunun hem de maltodekstrinin termal özellikleri mikrokapsüllerin özelliklerini etkilemektedir.

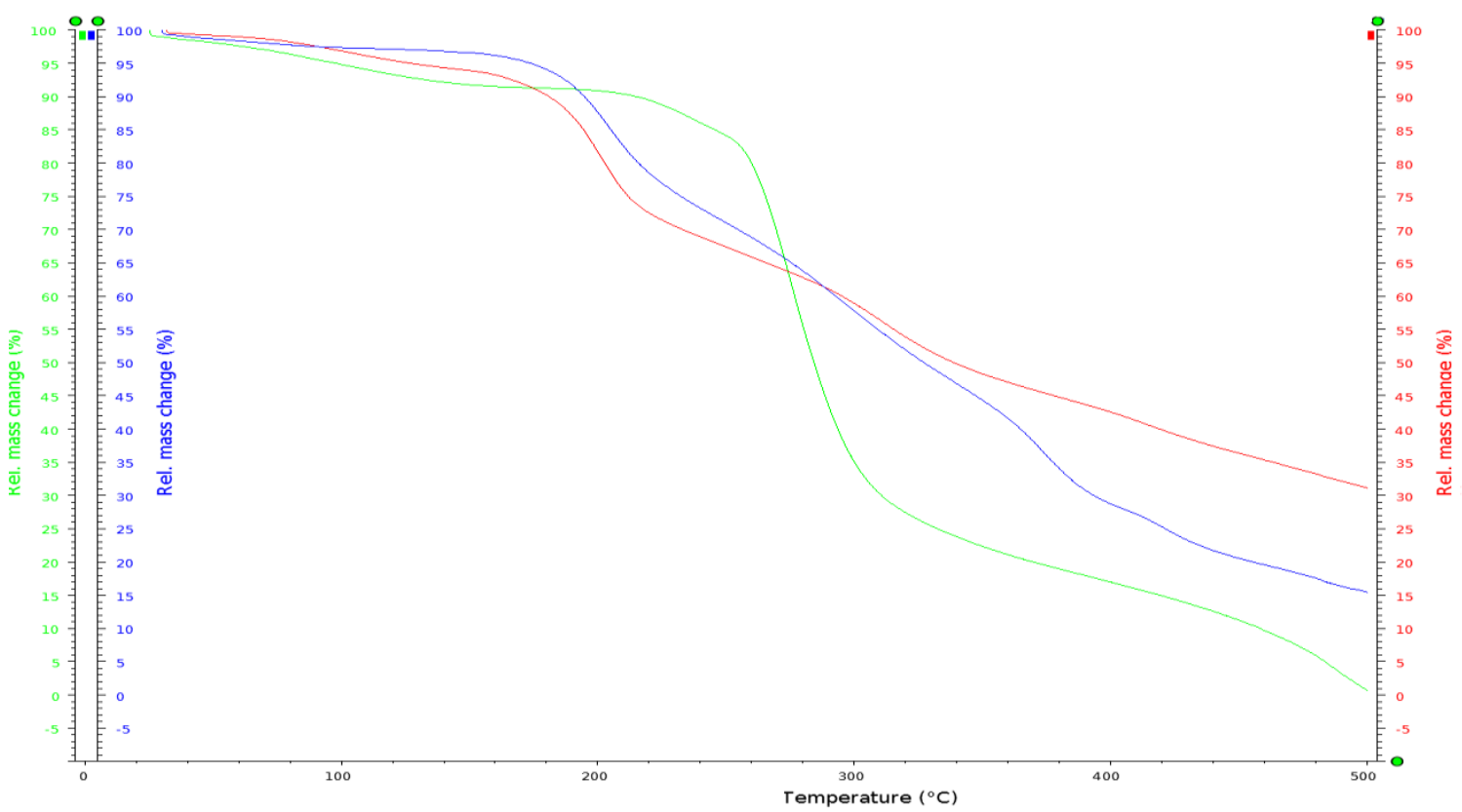

Şekil 3. Mikroenkapsüle tozların (Mavi), Maltodekstrin (Yeşil) ve yağsız süt tozuna (Kırmızı) ait termogravimetrik analiz sonuçları

Figure 3.Thermogravimetric analysis results of encapsulated powders (Blue), Maltodextrin (Green) and milk powder (Red)

\section{Morfolojik özellikler}

Mikrokapsüllerin taramalı elektron mikroskobu görüntüleri Şekil 4'te verilmiştir. Optimum kaplama maddesi karışımıla üretilen mikrokapsüller, dağınık yapıda küresel nispeten pürüzsüz bir yap1 göstermektedir. Bu şekilde yapıda mikrokapsüllerin üretilmiş olması depolamada yağın oksidasyondan korunarak uzun süreli depolanabileceğinin bir göstergesidir. Ayrıca, bu kaplama maddesi karışımı ile farklı boyutlarda mikrokapsüllerin oluştuğu ve uniform bir yapının olmadığı belirlenmiştir. Yağsız süt tozu ve maltodekstrin ile elde edilen mikrokapsüllerin topaklaşma göstermemektedir. Ancak bazı çalısmalarda farklı materyallerin mikroenkapsülasyonunda sadece yağsız süt tozu veya yağsız süt tozu+maltodekstrin kullanıldığında çukurlu yapıların oluştuğu rapor edilmiştir (Kalušević vd., 2017; Shamaei vd., 2017). Shamaei vd., (2017) tarafindan yapilan 
çalışmada $140^{\circ} \mathrm{C}$ giriş sıcaklı̆̆ında püskürtmeli kurutucu ile kaplama maddesi olarak $\% 50$ yağsiz süt tozu ve $\% 50$ maltodekstrin kullanıldığında ceviz yağı mikrokapsüllerinin çukurlu yapılar oluşturduğu görülmüş̧tür. $\mathrm{Bu}$ durum bizim çalışmamıza kiyasla düşük kurutma sıcaklığının kullanılması ile açıklanabilir.

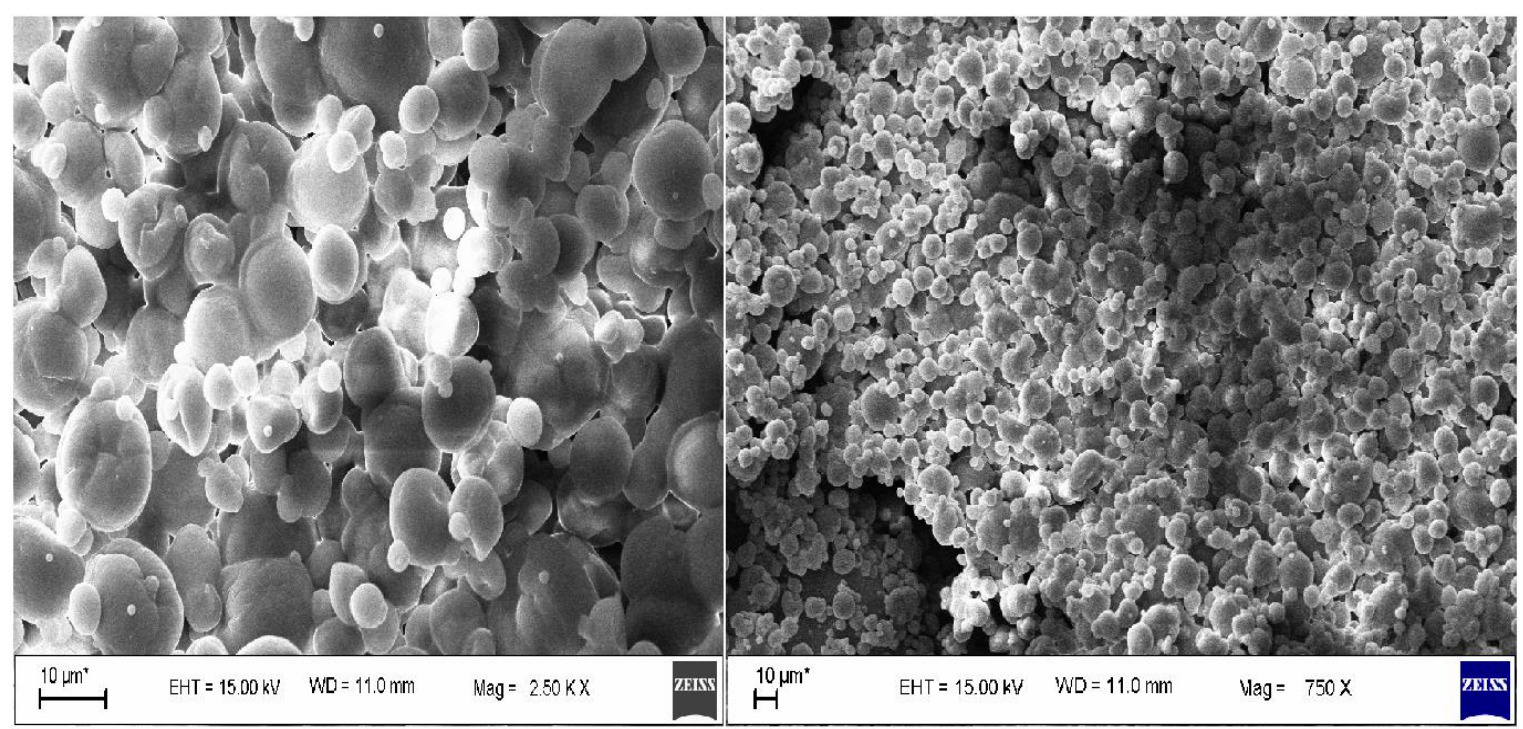

Şekil 4. Mikroenkapsüle tozların taramalı elektron mikroskobu görüntüleri

Figure 4. Scanning electron microscope images of encapsulated powders

\section{SONUÇ}

Bu çalışmada, kaplama maddesi olarak yağsız süt tozu ve maltodekstrin farklı oranlarda kombine edilerek KLA bakımdan zengin yağ mikroenkapsüle edilmiştir. Simplex Lattice deneme deseni kullanılarak belirlenen 8 farklı noktada mikroenkapsülasyon işlemi gerçekleştirilmiş ve mikroenkapsüle toz ürünlerin analizleri yürütülmüştür. Sadece maltodekstrin kullanılarak üretilen mikrokapsüller en düşük mikroenkapsülasyon verimi ve etkinliği değerlerini göstermiştir. Yapılan optimizasyon işlemi sonucunda, verim ve etkinlik değerlerini maksimize etmek için kullanılması gereken karışım oranları $\% 70$ yağsız süt tozu ve $\% 30$ maltodekstrin olarak belirlenmiştir. Elde edilen sonuçların uygunluğu doğrulama analizleri yapilarak belirlenmiştir. Optimum noktada elde edilen mikrokapsüller genellikle pürüzsüz yapılar göstermiştir. Kaplama maddesi ve yağ arasında moleküler olarak herhangi bir etkileşimin olmadığ1 mikroenkapsülasyonun fiziksel olarak gerçekleştiği belirlenmiştir. Ayrıca mikrokapsüllerin sıcaklık stabilitelerinin kullanılan kaplama maddesi ile ilişkili olduğu ortaya konulmuştur. Ancak üretilen tozlar istenmeyen özelliklerde akış özellikleri sergilemiştir. Bu sebeple yağsız süt tozu ile farklı kaplama maddelerinin kullanımı toz ürünlerin akış özelliklerini geliştirmek için araştırılmalıdır.

\section{ÇIKAR ÇATIŞMASI BEYANI}

Yazarlar arasında çıkar bulunmamaktadır.

\section{YAZAR KATKILARI}

HE, araştırmanın yürütülmesi, değerlendirilmesi ve yazımını sağlamışır. HA analizlerin planlanması, gerçekleştirilmesi, değerlendirilmesi ve yazımını sağlamıştır. Yazarlar makalenin son halini okumuş ve onaylamışlardır.

\section{TEŞEKKÜR}

Bu çalışma Niğde Ömer Halisdemir Üniversitesi Bilimsel Araştırma Projeleri Koordinasyon Birimi tarafindan desteklenen GTB 2018/05-BAGEP nolu "Mikrodalga Işınım ve Ultrases Dalgaları ile Konjüge Linoleik Asit Üretiminin Optimizasyonu ve Margarin Formülasyonunda Kullanımı" başlıklı proje kapsamında üretilmiştir. 


\section{KAYNAKLAR}

Aghbashlo, M., Mobli, H., Madadlou, A., Rafiee, S. (2012). The correlation of wall material composition with flow characteristics and encapsulation behavior of fish oil emulsion. Food Research International, 49(1), 379-388.

Aghbashlo, M., Mobli, H., Madadlou, A., Rafiee, S. (2013). Influence of wall material and inlet drying air temperature on the microencapsulation of fish oil by spray drying. Food and Bioprocess Technology, 6(6), 1561-1569.

Alaşalvar, H., Erinç, H., Salur, F., Özbey, A. (2019). Production of Conjugated Linoleic Acid by Microwave-Assisted and Ultrasound-Assisted Alkali Isomerization: Effects of Microwave Power and Ultrasound Amplitude. Journal of the American Oil Chemists' Society, 96(7), 839-846.

Başyiğit, B., Sağlam, H., Kandemir, Ş., Karaaslan, A., Karaaslan, M. (2020). Microencapsulation of sour cherry oil by spray drying: Evaluation of physical morphology, thermal properties, storage stability, and antimicrobial activity. Powder Technology, 364, 654-663. doi: https://doi.org/10.1016/j.powtec.2020.02.035

Choque, B., Catheline, D., Rioux, V., Legrand, P. (2014). Linoleic acid: between doubts and certainties. Biochimie, 96, 14-21.

Christy, A. A., Egeberg, P. K., Østensen, E. T. (2003). Simultaneous quantitative determination of isolated trans fatty acids and conjugated linoleic acids in oils and fats by chemometric analysis of the infrared profiles. Vibrational Spectroscopy, 33(12), 37-48.

Costa, a. M., Nunes, J., Lima, B., Pedrosa, C., Calado, V., Torres, A., Pierucci, A. (2015). Effective stabilization of CLA by microencapsulation in pea protein. Food Chemistry, 168, 157-166.

F. Gibbs, S. K., Inteaz Alli, Catherine N. Mulligan, Bernard. (1999). Encapsulation in the food industry: a review. International Journal of Food Sciences and Nutrition, 50(3), 213-224.

Fernandez-Avila, C., Arranz, E., Guri, A., Trujillo, A., Corredig, M. (2016). Vegetable protein isolatestabilized emulsions for enhanced delivery of conjugated linoleic acid in Caco-2 cells. Food Hydrocolloids, 55, 144-154.

Holgado, F., García-Martínez, M. C., Velasco, J., Ruiz-Méndez, M. V., Márquez-Ruiz, G. (2018). Microencapsulation of Conjugated Linoleic Acid (CLA)-Rich Oil with Skimmed Milk Components Protects against Polymerization. Journal of the American Oil Chemists' Society, 95(11), 1399-1408.

Goula, A. M., Adamopoulos, K. G. (2012). A method for pomegranate seed application in food industries: Seed oil encapsulation. Food and Bioproducts Processing, 90(4), 639-652.

Güney, A., Alaşalvar, H., Erinç, H. (2020). Margarin Formülasyonunda Konjüge Linoleik Asit Kullaniminin Depolama Stabilitesi Üzerine Etkisi. Gıda, 45(5), 997-1008.

Jimenez, M., Garcia, H., Beristain, C. (2004). Spray-drying microencapsulation and oxidative stability of conjugated linoleic acid. European Food Research and Technology, 219(6), 588-592.

Jimenez, M., Garcia, H., Beristain, C. (2006). Spray-dried encapsulation of conjugated linoleic acid (CLA) with polymeric matrices. Journal of the Science of Food and Agriculture, 86(14), 2431-2437.

Jinapong, N., Suphantharika, M., Jamnong, P. (2008). Production of instant soymilk powders by ultrafiltration, spray drying and fluidized bed agglomeration. Journal of Food Engineering, 84(2), 194-205.

Kadamne, J. V., Jain, V. P., Saleh, M., Proctor, A. (2009). Measurement of conjugated linoleic acid (CLA) in CLA-rich soy oil by attenuated total reflectance- fourier transform infrared spectroscopy (ATR- FTIR). Journal of Agricultural and Food Chemistry, 57(22), 10483-10488.

Kagami, Y., Sugimura, S., Fujishima, N., Matsuda, K., Kometani, T., Matsumura, Y. (2003). Oxidative stability, structure, and physical characteristics of microcapsules formed by spray drying of fish oil with protein and dextrin wall materials. Journal of Food Science, 68(7), 2248-2255.

Kalušević, A., Lević, S., Čalija, B., Pantić, M., Belović, M., Pavlović, V., Nedović, V. (2017). Microencapsulation of anthocyanin-rich black soybean coat extract by spray drying using 
maltodextrin, gum Arabic and skimmed milk powder. Journal of Microencapsulation, 34(5), 475487.

Kim, S. J., Park, G. B., Kang, C. B., Park, S. D., Jung, M. Y., Kim, J. O., Ha, Y. L. (2000). Improvement of oxidative stability of conjugated linoleic acid (CLA) by microencapsulation in cyclodextrins. Journal of Agricultural and Food Chemistry, 48(9), 3922-3929.

Kim, Y., Kim, J., Whang, K.-Y., Park, Y. (2016). Impact of conjugated linoleic acid (CLA) on skeletal muscle metabolism. Lipids, 51(2), 159178.

Labuschagne, P. (2018). Impact of wall material physicochemical characteristics on the stability of encapsulated phytochemicals: A review. Food Research International, 107, 227-247. doi: https://doi.org/10.1016/j.foodres.2018.02.026

Lee, J.-S., Song, Y.-B., Lee, J. Y., Kim, M. K., Jun, S. J., Lee, H. G. (2009). Optimization and oxidative stability of the microencapsulated conjugated linoleic acid. International Journal of Biological Macromolecules, 45(4), 348-351.

Nath, S., ve Satpathy, G. R. (1998). A systematic approach for investigation of spray drying processes. Drying Tecbnology, 16(6), 1173-1193.

Roach, J. A., Mossoba, M. M., Yurawecz, M. P., Kramer, J. K. (2002). Chromatographic separation and identification of conjugated linoleic acid isomers. Analytica Chimica Acta, 465(1-2), 207-226.

Roccia, P., Martínez, M. L., Llabot, J. M., Ribotta, P. D. (2014). Influence of spray-drying operating conditions on sunflower oil powder qualities. Powder Technology, 254, 307-313.

Shamaei, S., Seiiedlou, S. S., Aghbashlo, M., Tsotsas, E., Kharaghani, A. (2017). Microencapsulation of walnut oil by spray drying: Effects of wall material and drying conditions on physicochemical properties of microcapsules. Innovative Food Science \& Emerging Technologies, 39, 101-112. doi: https://doi.org/10.1016/j.ifset.2016.11.011

Tonon, R. V., Grosso, C. R., Hubinger, M. D. (2011). Influence of emulsion composition and inlet air temperature on the microencapsulation of flaxseed oil by spray drying. Food Research International, 44(1), 282-289.

Torres-Giner, S., Martinez-Abad, A., Ocio, M. J., Lagaron, J. M. (2010). Stabilization of a nutraceutical omega-3 fatty acid by encapsulation in ultrathin electrosprayed zein prolamine. Journal of Food Science, 75(6), N69-N79.

Velasco, J., Marmesat, S., Dobarganes, C., Márquez-Ruiz, G. (2006). Heterogeneous aspects of lipid oxidation in dried microencapsulated oils. Journal of Agricultural and Food Chemistry, 54(5), 1722-1729. 